\title{
Static Stress Transfer between the Chinshan and Shanchiao Faults in the Taipei Metropolitan Area
}

\author{
Jeng-Cheng Wang ${ }^{1,2, *}$, Jeen-Hwa Wang ${ }^{2}$, Chiou-Fen Shieh ${ }^{3}$, and Yih-Hsiung Yeh ${ }^{2}$ \\ ${ }^{1}$ Department of Applied Geoinformatics, Chia Nan University of Pharmacy and Science, Tainan, Taiwan, ROC \\ ${ }^{2}$ Institute of Earth Sciences, Academia Sinica, Taipei, Taiwan, ROC \\ ${ }^{3}$ Institute of Seismology, National Chung-Cheng University, Chiayi, Taiwan, ROC
}

Received 11 May 2008, accepted 24 November 2009

\begin{abstract}
In the Taipei Metropolitan Area, there is a significant problem to be resolved: Can two major active faults, i.e., the Chinshan and Shanchiao faults fail simultaneously? The two faults are both normal faulting based upon recent observations. In order to explore this problem, the static stress transfer between the two faults has been analyzed. We compute the static Coulomb failure stress changes, $\triangle C F S$, on a fault plane due to a failure of the neighboring fault. Numerical computations are conducted for the combinations of three different dip and rake angles of the two fault planes. Results show that the Chinshan fault can be more likely triggered by a failure of the Shanchiao fault. Rupture of a fault is more capable of triggering the neighboring fault, when the rake angle of the ruptured fault is toward than opposite to the striking direction of the to-be-triggered fault.
\end{abstract}

Key words: Stress transfer, Static Coulomb failure stress, Triggering rupture, Taipei basin

Citation: Wang, J. C., J. H. Wang, C. F. Shieh, and Y. H. Yeh, 2010: Static stress transfer between the Chinshan and Shanchiao faults in the Taipei metropolitan area. Terr. Atmos. Ocean. Sci., 21, 515-527, doi: 10.3319/TAO.2009.11.24.01(TH)

\section{INTRODUCTION}

Static stress transfer between two faults or fault segments is an important problem not only of academic interest but also for practical needs in seismic risk mitigation. In past, the study was focused generally on faults with the same mechanism (cf. Segall and Pollard 1980). However, in some seismically active areas, e.g., Taiwan, there are faults systems consisting of faults with different mechanisms giving rise to the importance of investigating static stress transfer between such fault systems. In this work, we will focus on a system with two important normal faults in the Taipei Metropolitan Area (TMA). We believe that the results of this study can be applied to other areas with similar fault systems.

Taiwan is situated on the collision boundary between the Philippine Sea and Eurasian plates (Wu 1978; Lin 2002). The former is moving northwestward with a speed of $8 \mathrm{~cm} \mathrm{yr}^{-1}$ and colliding the latter. The Philippine Sea plate has subducted underneath northern Taiwan, in which the

\footnotetext{
* Corresponding author

E-mail:jcwang@mail.chna.edu.tw
}

TMA is located. This collision causes high seismicity in the Taiwan region (Wang 1998).

The TMA is the political, economic, and cultural center of Taiwan with more than 4 million peoples, which is together with a rapid growth in population and vehicles. A large numbers of high-rises used for living or working have been constructed and a complex rapid transportation system (Taipei Metro system) has been operated several years. In addition to the important constructions, there are two functioning nuclear power plants located in the vicinity of the area. Thus, it is the necessitating continuous evaluation and re-evaluation of seismic risk mitigation in this area.

There are numerous active faults in the area. Out of them, two active faults, i.e., the Chinshan and Shanchiao faults, are particularly important, because they are considered to be related to a large historical earthquake of $\mathrm{M}=7$, which might result in a lake, occurred in the Emperor Kanshi period of Ching Dynasty in 1694 (Hsu 1983). In order to form a lake, the average vertical displacement caused by the event should be several meters. Of course, there are debates about the possibility of the occurrence of this event. In order 
to explore the problem, two questions should be answered. How big will be the largest earthquakes individually rupturing the Chinshan and Shanchiao faults? Can the two faults fail simultaneously?

Although a large number of geological surveys were conducted along the 2 faults (see CGS 2000, 2007), a few fault parameters (e.g., fault width, average displacement, etc.) which are necessary for simulations are still unknown. Hence, each fault is freely changeable with a small constraint because there is only limited geological and seismological information. For the first question related in last paragraph, Shyu et al. (2005) used the proposed fault area to estimate an earthquake, while Wang (2008) used the fault length to do the same thing. In this study, we will tackle the second question. Although the Chinshan and Shanchiao faults are, respectively, a thrust fault and a normal fault in past study (Lin et al. 2000), based on the recent LiDAR survey, researchers at the Institute of Earth Sciences, Academia Sinica did find some steep normal fault scarps near the Chinshan fault trace (Chan et al. 2005a, b). In addition, many studies indicate or suggest that the Chinshan fault has now reactivated as a normal fault (Shyu et al. 2005). Meanwhile, the Chinshan fault is on the Tatun Volcano Group, the geotemperature below it would be higher than that beneath the Shanchiao fault (cf. Wang 1988; Wang et al. 1994; Kim et al. 2005; Lin et al. 2005). In order to answer the question, simulations on the basis of a mechanical model are needed.
In order to study the triggering and rupture of an earthquake, it is necessary to calculate dynamic (instant static) stress change on a fault plane and its effect on adjacent faults and the patches on the source fault during the rupture processes. Because no earthquake has occurred along the Chinshan and Sanchaio faults for a long time, there is a lack of detailed information of source rupture processes along the two faults giving rise to the difficulty in estimating the spatial distributions of source parameters to calculate dynamic (instant static) stress changes. This work is an attempt to answer the second question by computing static Coulomb failure stress changes on a fault plane caused by the failure of the neighboring fault. The parameters of static Coulomb failure stress changes include average slip, fault type, and size. It is easy to estimate these source parameters on the basis of given geological and seismological information.

\section{THE TAIPEI METROPOLITAN AREA}

The TMA is situated on the Taipei Basin, which is a sedimentary basin (see Fig. 1)(Wang-Lee et al. 1987; Chang et al. 1998; CGS 1999; Wang et al. 2004). In the basin, Quaternary sediments lie within a Tertiary basement. The Quaternary sediments are composed of the Sungshan, Chingmei, and Hsinchuang formations from top to bottom. Teng et al. (1994) further divided the Hsinchuang formation into two, i.e., the Wuku and Panchiou formations. The topmost

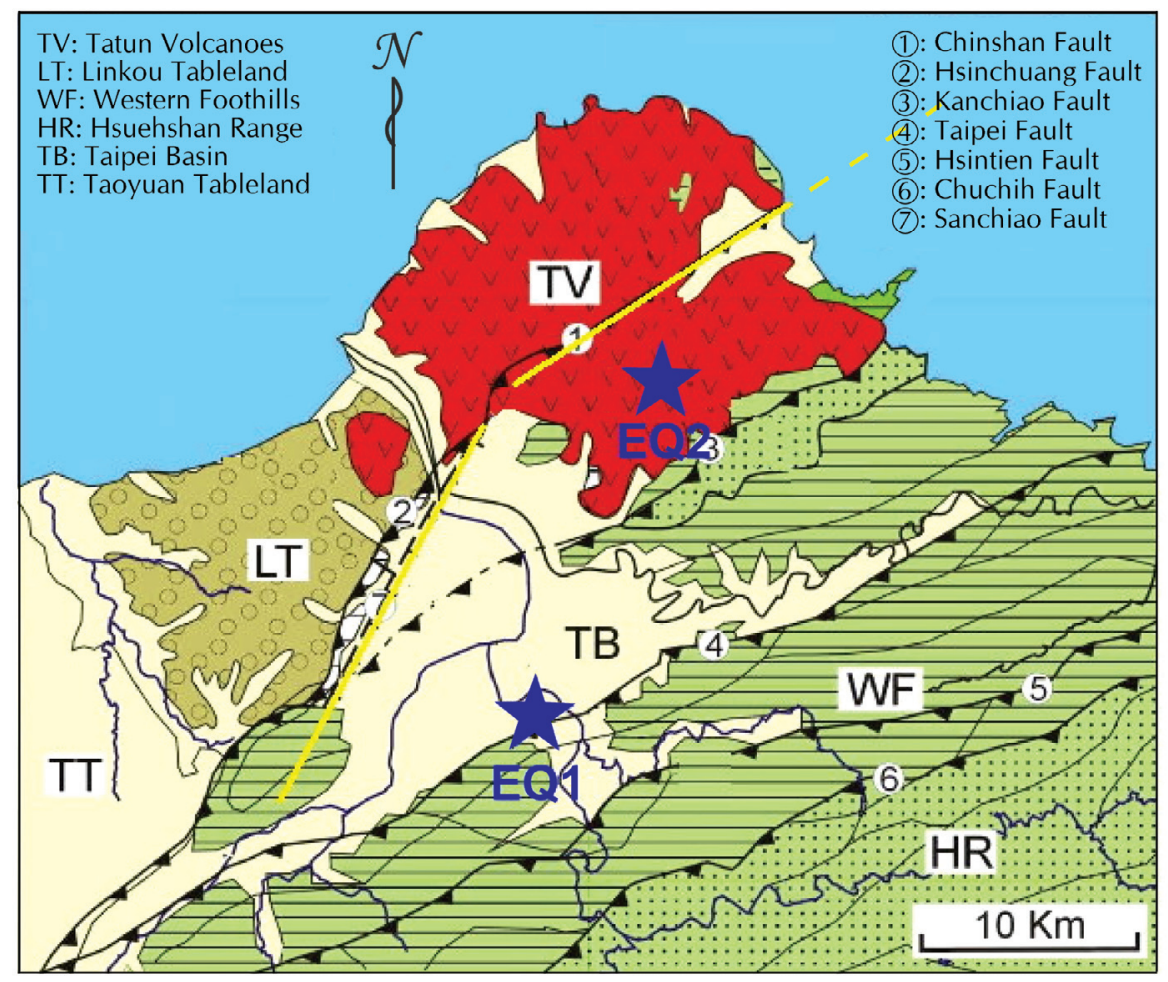

Fig. 1. Geology of the Taipei Metropolitan Area, including the Taipei Basin, the Tatun Volcanoes, the Western Foothill, and the Linkou Tableland (after Teng et al. 1994). 
part of the Sungshan formation is a soft layer, composed of unconsolidated sand, silt and clay with a thickness varying from $50 \mathrm{~m}$ in the southeast to $120 \mathrm{~m}$ in northwest. The lower part of the formation is dominated by silt. The Chingmei formation is full of gravel. The Hsinchuang formation is composed of sand and silt.

From the Piocene to the Peistocene, three large reverse faults developed along the western boundary of the Western Foothills. From west to east, the three faults are the Hsinchuang fault, the Kanchiao fault, and the Taipei fault, all trending in the NE-SW direction. In that time, the Linkou area was a delta fan at the foot of these fault-created hills, where conglomerates were widely deposited. About 400 thousand years ago, the tectonic condition in northern Taiwan changed from that of compression to tension. A segment of the Hsinchung fault re-activated as a normal fault. This segment is called the Shanchiao fault. (Re-activation of this fault as a normal fault indicates that the fault could be still active and would result in a different size of an impending earthquake as compared to a thrust fault. This is significant for assessment of seismic hazards in the area.) This tension-type tectonics led to a pull-apart mechanism which made the Taipei basin subside. Thus, the deepest portion of the basin is along the NW border where the Shanchiao fault is located. This results in a half-bowl-shape basin. The cut boundary is close along the Shanchiao fault. The basement is shallower than $250 \mathrm{~m}$ in the south and deeper than $500 \mathrm{~m}$ in the north. This might be caused by the formation of the Shanchiao fault. Bonilla (1977) proposed that the Shanchiao fault is quite young and moved in the recent past and means that this fault could be active in the future. The old Kanchiao fault produced uplift in the basement, thus forming a geological boundary to separate the basin into two parts, which have different basement depths and deposits.

From the contour maps created from the leveling data during 1975 - 2003, Chen et al. (2007a) observed that the subsidence rate in the Taipei Basin gradually decreased beginning in 1975 and exhibited a slight uplift throughout a large part of the basin beginning 2003. They proposed three mechanisms, shallow soil compaction, deformation within an aquifer, and tectonic subsidence to interpret the observations. The trend of the ground level change from 1975 - 2003 essentially showed a natural recharge to previously depleted aquifers and explained by "elastic rebound." The rate of shallow soil compaction was $\sim 18 \mathrm{~mm} \mathrm{yr}^{-1}$ throughout the basin. Asymmetric tectonic subsidence related to the Shanchiao fault was $\sim 1.75$ and $\sim 0.9 \mathrm{~mm} \mathrm{yr}^{-1}$ in the western part and center of the basin, respectively. The amount of rebound is $10 \%$ in magnitude compared to the amount of previous anthropogenic subsidence due to massive ground pumping, about $2 \mathrm{~m}$.

Although seismicity is lower in the TMA than in others of Taiwan, numerous earthquakes still occur near or in the area (Hsu 1961, 1983; Wang 1998). Radiocarbon dating from drilled cores suggests that three prehistoric earthquakes ruptured the Shanchiao fault in the past 11000 years, and the latest event occurred around 8400 years ago (Huang et al. 2003). The occurrence times, locations, magnitudes, and effects of a few $\mathrm{M}>5$ earthquakes occurring in or near the area are given in Table 1. The errors of locations and magnitudes of earthquakes occurring before 1900 are high. An event which was assumed to occur in April or May of 1694 during reign of the Emperor Kanshi of the Ching Dynasty resulted in an earthquake induced lake and the destruction of aboriginal homes (Lin 1957; Hsu 1983). From historical documents pertaining to damage, the magnitude of this event has been estimated by Hsu (1983) and Tsai (1985) to be about 7 . Of course, there are debates about the possibility of the occurrence of this event.

Wang et al. (2006a) investigated the epicentral distribution, depth distribution, and temporal sequences of $\mathrm{M} \geq 4$ earthquakes in the TMA from 1973 - 2005. They divided the earthquakes into two groups, with a depth difference of about $20 \mathrm{~km}$ : one for shallow events with focal depths ranging $0-40 \mathrm{~km}$ and the other with focal depths larger than $60 \mathrm{~km}$. The deep events occurred along the subduction zone with a dip angle of about $70^{\circ}$. Shallow earthquakes mainly located in depth range from $0-10 \mathrm{~km}$ north of $25.1^{\circ} \mathrm{N}$, and down to $35 \mathrm{~km}$ for those south of $25.1^{\circ} \mathrm{N}$. After 1988; no $M \geq 4$ shallow event was located within this area. Deep

Table 1. The $M>5$ earthquakes about the Taipei Metropolitan Area.

\begin{tabular}{llll}
\hline Time & Location & M & Effects \\
\hline $1694 / 4-5$ & Near Taipei & 7 & Formation of the Kanshi Lake and damaged houses \\
$1815 / 7 / 11$ & Near Taipei & 6.5 & Minor damages \\
$1867 / 12 / 18$ & Offshore Keelung & 7 & Tsunami; Surface ruptures; Death \\
$1909 / 04 / 15(\mathrm{EQ} 1)$ & $25^{\circ} \mathrm{N}, 121.5^{\circ} \mathrm{E} ;$ Focal depth $=80 \mathrm{~km}$ & 7.3 & Death: $9 ;$ Injured: 51 ; Houses - Collapsed: $122 ;$ Damaged: 1050 \\
$1988 / 07 / 03(\mathrm{EQ} 2)$ & $25.16^{\circ} \mathrm{N}, 121.57^{\circ} \mathrm{E} ;$ Focal depth $=5 \mathrm{~km}$ & 5.3 & Injured: 16 \\
\hline
\end{tabular}


events occurred more or less uniformly during the study period. The annual number of shallow earthquakes decreased with time from 1973 to 1988 and varies year to year for deep events. However, seismicity was low in the area around the two faults. From re-located earthquake data, Kim et al. (2005) observed a cluster of events below the Chinshan fault, and also stressed that clustered seismicity trends with inconsistent dipping directions are manifest, and, in particular, a dominant linear southeast dipping seismicity trend is readily identifiable. From the data obtained from a micro-earthquake survey in the Taipei Basin during the period from 17 June to 20 September 2004, Chen et al. (2010) observed that seismicity on and around the Shanchiao fault is very low. They also found that three felt earthquakes occurred near the eastern part of the Taipei basin, about $3 \mathrm{~km}$ to the south of Taipei 101. Relocated earthquakes show a southeast-dipping distribution of hypocenters beneath the Taipei basin. From the seismicity pattern and focal mechanisms of the three felt events, they suggest the existence of a blind normal fault, whose surface project is along the river channel in the middle of the basin. Lin (2005) also studied the three events. However, they had a different idea about the occurrence of those events.

In spite of larger-sized earthquakes have ever occurred in the TMA, the length of the Shanchiao fault could be $40 \mathrm{~km}$ long from CGS (2008). The magnitude of an impending earthquake which would potentially rupture the faults could be at least 7 .

\section{AVERAGE DISPLACEMENT ESTIMATES OF THE CHINSHAN AND SHANCHIAO FAULTS}

To compute stress transfer, the average displacement on a fault plane must be first estimated. The lengths of the Shanchiao and Chinshan faults are, respectively, 20 and 25 km (Shyu et al. 2005; Wang 2008). From Table 2c in Well and Coppersmith (1994), the average displacements, $D_{\text {ave }}$, of earthquakes individually rupturing the two faults can be evaluated from the following relationships:

$\log \left(\mathrm{D}_{\text {ave }}\right)=(-1.99 \pm 0.72)+(1.24 \pm 0.49) \times \log (\mathrm{L})$

where $\mathrm{L}$ is the fault length.

\subsection{For the Shanchiao Fault}

From Eq. (1), $\mathrm{L}=20 \mathrm{~km}$, we have $0.018 \mathrm{~m} \leqq \mathrm{D}_{\text {ave }}=$ $0.42 \mathrm{~m} \leqq 9.57 \mathrm{~m}$. The optimum value of $\mathrm{D}_{\text {ave }}$ is $0.42 \mathrm{~m}$. The upper bound of $\mathrm{D}_{\text {ave }}$ is $9.57 \mathrm{~m}$, which might be overestimated due to a high uncertainty of the inference of Eq. (1) for large magnitudes because of limited data. The seismic moment, $\mathrm{M}_{\mathrm{o}}$, is defined to be $\mu \mathrm{AD}_{\text {ave }}$, where $\mu$ (= 3 $\times 10^{11}$ dyne $\mathrm{cm}^{-2}$ ) and $\mathrm{A}$ are the average rigidity of crustal materials and the fault area, respectively. Hence, we have
$0.22 \times 10^{25}$ dyne-cm $\leqq \mathrm{M}_{\mathrm{o}}=5.04 \times 10^{25}$ dyne-cm $\leqq 1.15 \times$ $10^{27}$ dyne-cm, because of $\mathrm{A}=4.0 \times 10^{12} \mathrm{~cm}^{2}$. On the basis of the scaling law between $\mathrm{M}_{\mathrm{o}}$ and $\mathrm{M}_{\mathrm{s}}$ for Taiwan's earthquakes (Chen et al. 2007b): $\log \left(\mathrm{M}_{\mathrm{o}}\right)=1.07 \mathrm{M}_{\mathrm{s}}+18.72\left(\mathrm{M}_{\mathrm{o}}\right.$ in dyne-cm), we have $5.2 \leqq \mathrm{M}_{\mathrm{s}}=6.5 \leqq 7.8$. On the other hand, from the fault length the magnitude is $5.9 \leqq \mathrm{M}_{\mathrm{s}} \leqq 7.3$ by Wang (2008). Obviously, the magnitude range inferred from the fault length is shorter than that from the fault area.

\subsection{For the Chinshan Fault}

Using the same Eq. (1), but $\mathrm{L}=25 \mathrm{~km}$, we have $0.022 \mathrm{~m} \leqq \mathrm{D}_{\text {ave }}=0.55 \mathrm{~m} \leqq 14.07 \mathrm{~m}$. The most optimum value of $D_{\text {ave }}$ is $0.55 \mathrm{~m}$. The upper bound of $D_{\text {ave }}$ is $14.07 \mathrm{~m}$, which might be overestimated due to a high uncertainty of the inference of Eq. (1) for large magnitudes because of limited data. On the basis of the procedure as mentioned above, we have $5.1 \leqq \mathrm{M}_{\mathrm{s}}=6.4 \leqq 7.8$, because of $\mathrm{A}=2.5 \times 10^{12} \mathrm{~cm}^{2}$. On the other hand, from the fault length the magnitude is $6.0 \leqq \mathrm{M}_{\mathrm{s}} \leqq 7.4$ by Wang (2008). Obviously, the magnitude range inferred from the fault length is shorter than that from the fault area.

Wang (1988) stated that the b-value is higher in northern Taiwan than in other areas. This might be due to higher geo-temperature in northern Taiwan caused by past volcanic activity. Wang et al. (1994) also stated that except for the earthquakes in the Wadati-Benioff subduction zone, the events occurring in northern Taiwan are usually shallow and implies that the seismogenic zone below the Tatun Volcano Group (TVG) would be thinner than others. Lin et al. (2005) stated that the earthquakes occurring underneath the TVG are located mainly in the depth range of $2-4 \mathrm{~km}$. Wang et al. (2006a) found that the shallow $M \geq 4$ earthquakes occurring in the area were located at depths from 0 to $35 \mathrm{~km}$. From Scholz (1990), these studies imply that the seismogenic zone below the TVG would be thinner than others. The fault width would be smaller for the Chinshan fault than for the Shanchiao fault. In this study, the fault widths of the two faults are 10 and $20 \mathrm{~km}$ for the Chinshan and Shanchiao faults, respectively. However, Wang and $\mathrm{Ou}$ (1998) found that the main factor in controlling the displacement is the fault length rather than the fault width. Hence, the calculated value of $D_{\text {ave }}$ from Eq. (1) can be accepted for the Chinshan fault.

\section{NUMERICAL COMPUTATIONS}

The Shanchiao and Chinshan faults are both normal faulting. Their ground surface traces are shown in Fig. 1 with two thick yellow lines. In order to investigate interaction between the two faults, we evaluate static stress transfer from one to the other. Since detailed information of the two faults is not available, some assumptions on the geometrical patterns are necessary. The fault planes of the Shanchiao 
and Chinshan faults are considered to be two rectangles of $20 \times 20 \mathrm{~km}^{2}$ and $25 \times 10 \mathrm{~km}^{2}$, respectively. In the following computations, the dip and rake angles are denoted by $\theta$ and $\phi$, respectively. Meanwhile, the subscripts " $S$ " and " $C$ " represent the Shanchiao and Chinshan faults, respectively. From ground surface traces, the strike angles are $27.8^{\circ}$ and $56.8^{\circ}$, respectively, for the former and the latter. Since the values of $\theta$ for the two faults are unknown, three test values, i.e., $45^{\circ}, 60^{\circ}$, and $75^{\circ}$ for the Shanchiao and the Chinshan (normal) faults are taken for numerical computations. Similarly, three test values of $\phi$, i.e., $-45^{\circ}$ (for the fault with both normal and left-lateral components), $-90^{\circ}$ (purely normal), and $-135^{\circ}$ (for the fault with both normal and right-lateral components) for the Shanchiao and the Chinshan faults, are taken into account. As mentioned above, the upper bound of $D_{\text {ave }}$ of the Shanchiao and Chinshan faults are 9.57 and $14.07 \mathrm{~m}$, respectively. To calculate local static stress changes on a fault plane caused by failure of the other, we apply the computing codes (PSGRN/PSCMP), in which a layered crustal and upper-mantle model is considered, developed by Wang et al. (2006b). Although the codes are based on the viscoelastic- gravitational dislocation theory, only the elastic media is taken into account in this study. The velocity model under the study area, which is taken from Chen et al. (1998)(i.e., Block I in their Table 1), is listed in Table 2. The P-wave velocity $\left(\mathrm{V}_{\mathrm{p}}\right)$ comes from $\sqrt{3}$ multiplied by the S-wave one $\left(\mathrm{V}_{\mathrm{s}}\right)$.

The static Coulomb failure stress changes $\triangle C F S$ on a fault plane (King et al. 1994; Toda et al. 1998; Wang et al. 2003) caused by a nearby fault rupture is,

$\Delta C F S=\Delta \tau+\mu \Delta \sigma_{n}$

where $\Delta \tau$ and $\Delta \sigma_{n}$ are, respectively, the static shear stress change (positive along the slip direction) and effective normal stress change (positive for unclamping), and $\mu$ is the static friction coefficient. The value of $\mu$ normally lies between 0.6 and 1.0 (Townend and Zoback 2000), and its lower bound, i.e., 0.6, is taken for the following computations. The criterion of stability of a fault plane is: unstable as $\triangle C F S>0$ and stable as $\triangle C F S<0$.

\section{RESULTS}

The faults parameters (including dips, rakes, and slip) and the corresponding results are illustrated in Table 3.

\subsection{Purely Normal Faults}

Considering the case that the Shanchiao fault which is a purely normal fault with $\phi_{\mathrm{S}}=-90^{\circ}$ first breaks, the spatial distributions of $\triangle C F S$ for $\theta_{\mathrm{C}}=45^{\circ}, 60^{\circ}$, and $75^{\circ}$ on the Chinshan fault plane caused by the former, with $\theta_{\mathrm{S}}=45^{\circ}$, $60^{\circ}$, and $75^{\circ}$ and $\mathrm{D}_{\text {aves }}=9.57 \mathrm{~m}$, are depicted in Fig. 2: (1)
Table 2. The velocity model (after Chen et al. 1998).

\begin{tabular}{cccc}
\hline Depth $(\mathbf{k m})$ & $\left.\mathbf{V}_{\mathrm{p}}(\mathbf{k m ~ s})^{-1}\right)$ & $\mathbf{V}_{\mathrm{s}}\left(\mathbf{k m ~ s}^{-1}\right)$ & Density $\left(\mathbf{g ~ c m}^{-3}\right)$ \\
\hline 2 & 4.95 & 2.86 & 2.40 \\
5 & 5.14 & 2.97 & 2.40 \\
10 & 5.54 & 3.20 & 2.50 \\
15 & 6.04 & 3.49 & 2.60 \\
25 & 6.60 & 3.81 & 2.85 \\
35 & 7.17 & 4.14 & 3.15 \\
Half space & 7.43 & 4.29 & 3.30 \\
\hline
\end{tabular}

Table 3. The fault parameters and the corresponding results.

\begin{tabular}{|c|c|c|c|c|}
\hline \multirow{2}{*}{\multicolumn{2}{|c|}{ Breaking Fault }} & \multicolumn{3}{|c|}{ Chinshan fault } \\
\hline & & $\theta_{\mathrm{C}}=45^{\circ}$ & $\theta_{\mathrm{C}}=60^{\circ}$ & $\theta_{\mathrm{C}}=75^{\circ}$ \\
\hline \multirow{3}{*}{$\begin{array}{l}\text { Shanchiao fault } \\
\phi_{\mathrm{S}}=-90^{\circ} \\
\mathrm{D}_{\text {aves }}=9.57 \mathrm{~m}\end{array}$} & $\theta_{\mathrm{S}}=45^{\circ}$ & Fig. 2a & Fig. 2b & Fig. 2c \\
\hline & $\theta_{\mathrm{S}}=60^{\circ}$ & Fig. 2d & Fig. 2e & Fig. $2 f$ \\
\hline & $\theta_{\mathrm{S}}=75^{\circ}$ & Fig. $2 g$ & Fig. $2 \mathrm{~h}$ & Fig. $2 \mathrm{i}$ \\
\hline \multirow{3}{*}{$\begin{array}{l}\text { Shanchiao fault } \\
\phi_{\mathrm{S}}=-45^{\circ} \\
\mathrm{D}_{\text {aves }}=9.57 \mathrm{~m}\end{array}$} & $\theta_{\mathrm{S}}=45^{\circ}$ & Fig. $4 \mathrm{a}$ & Fig. $4 b$ & Fig. $4 \mathrm{c}$ \\
\hline & $\theta_{\mathrm{S}}=60^{\circ}$ & Fig. 4d & Fig. 4e & Fig. $4 \mathrm{f}$ \\
\hline & $\theta_{\mathrm{S}}=75^{\circ}$ & Fig. 4g & Fig. 4h & Fig. $4 \mathrm{i}$ \\
\hline \multirow{3}{*}{$\begin{array}{l}\text { Shanchiao fault } \\
\phi_{\mathrm{S}}=-135^{\circ} \\
\mathrm{D}_{\text {aves }}=9.57 \mathrm{~m}\end{array}$} & $\theta_{\mathrm{S}}=45^{\circ}$ & Fig. $5 \mathrm{a}$ & Fig. $5 b$ & Fig. $5 \mathrm{c}$ \\
\hline & $\theta_{\mathrm{s}}=60^{\circ}$ & Fig. 5d & Fig. 5e & Fig. $5 f$ \\
\hline & $\theta_{\mathrm{S}}=75^{\circ}$ & Fig. $5 \mathrm{~g}$ & Fig. 5h & Fig. $5 i$ \\
\hline \multirow{2}{*}{\multicolumn{2}{|c|}{ Breaking Fault }} & \multicolumn{3}{|c|}{ Shanchiao fault } \\
\hline & & $\theta_{\mathrm{S}}=45^{\circ}$ & $\theta_{\mathrm{S}}=60^{\circ}$ & $\theta_{\mathrm{S}}=75^{\circ}$ \\
\hline \multirow{3}{*}{$\begin{array}{l}\text { Chinshan fault } \\
\phi_{\mathrm{C}}=-90^{\circ} \\
\mathrm{D}_{\text {aveC }}=14.07 \mathrm{~m}\end{array}$} & $\theta_{\mathrm{C}}=45^{\circ}$ & Fig. $3 a$ & Fig. 3b & Fig. $3 c$ \\
\hline & $\theta_{\mathrm{C}}=60^{\circ}$ & Fig. 3d & Fig. 3e & Fig. 3f \\
\hline & $\theta_{\mathrm{C}}=75^{\circ}$ & Fig. $3 g$ & Fig. 3h & Fig. $3 i$ \\
\hline \multirow{3}{*}{$\begin{array}{l}\text { Chinshan fault } \\
\phi_{\mathrm{C}}=-45^{\circ} \\
\mathrm{D}_{\text {aveC }}=14.07 \mathrm{~m}\end{array}$} & $\theta_{\mathrm{C}}=45^{\circ}$ & Fig. 6a & Fig. 6b & Fig. $6 \mathrm{c}$ \\
\hline & $\theta_{\mathrm{C}}=60^{\circ}$ & Fig. 6d & Fig. 6e & Fig. 6f \\
\hline & $\theta_{\mathrm{C}}=75^{\circ}$ & Fig. $6 \mathrm{~g}$ & Fig. 6h & Fig. $6 \mathrm{i}$ \\
\hline \multirow{3}{*}{$\begin{array}{l}\text { Chinshan fault } \\
\phi_{C}=-135^{\circ} \\
D_{\text {aveC }}=14.07 \mathrm{~m}\end{array}$} & $\theta_{\mathrm{C}}=45^{\circ}$ & Fig. 7a & Fig. 7b & Fig. 7c \\
\hline & $\theta_{\mathrm{C}}=60^{\circ}$ & Fig. 7d & Fig. 7e & Fig. 7f \\
\hline & $\theta_{\mathrm{C}}=75^{\circ}$ & Fig. $7 g$ & Fig. 7h & Fig. $7 i$ \\
\hline
\end{tabular}



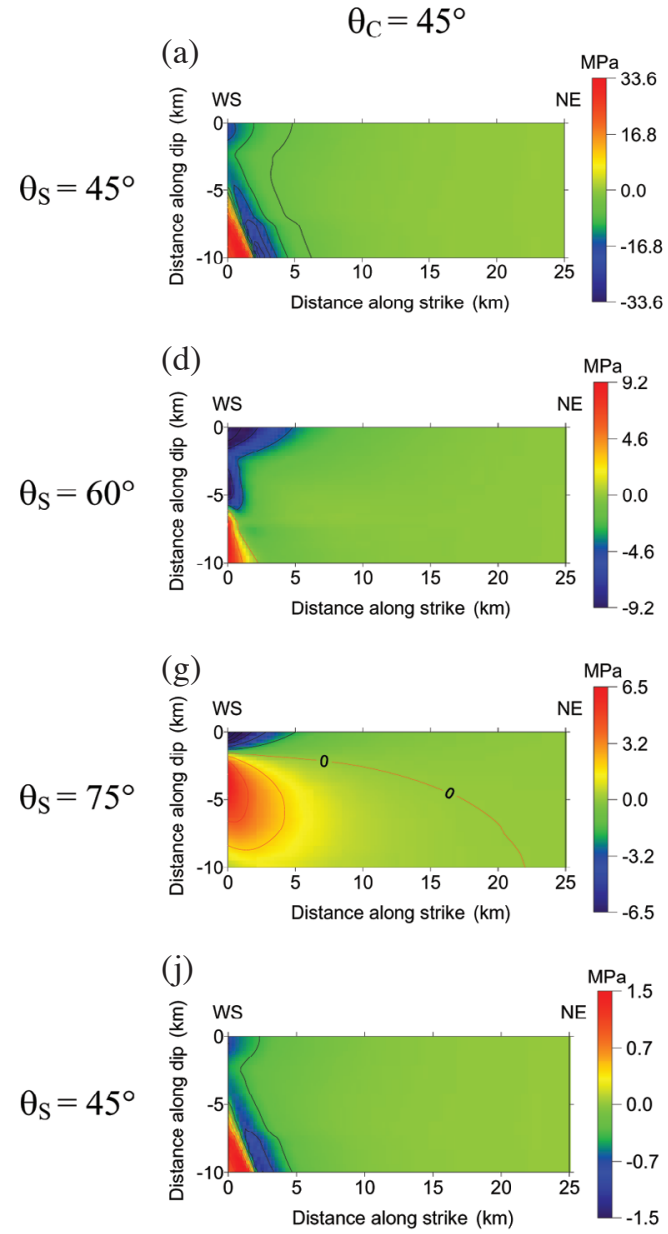
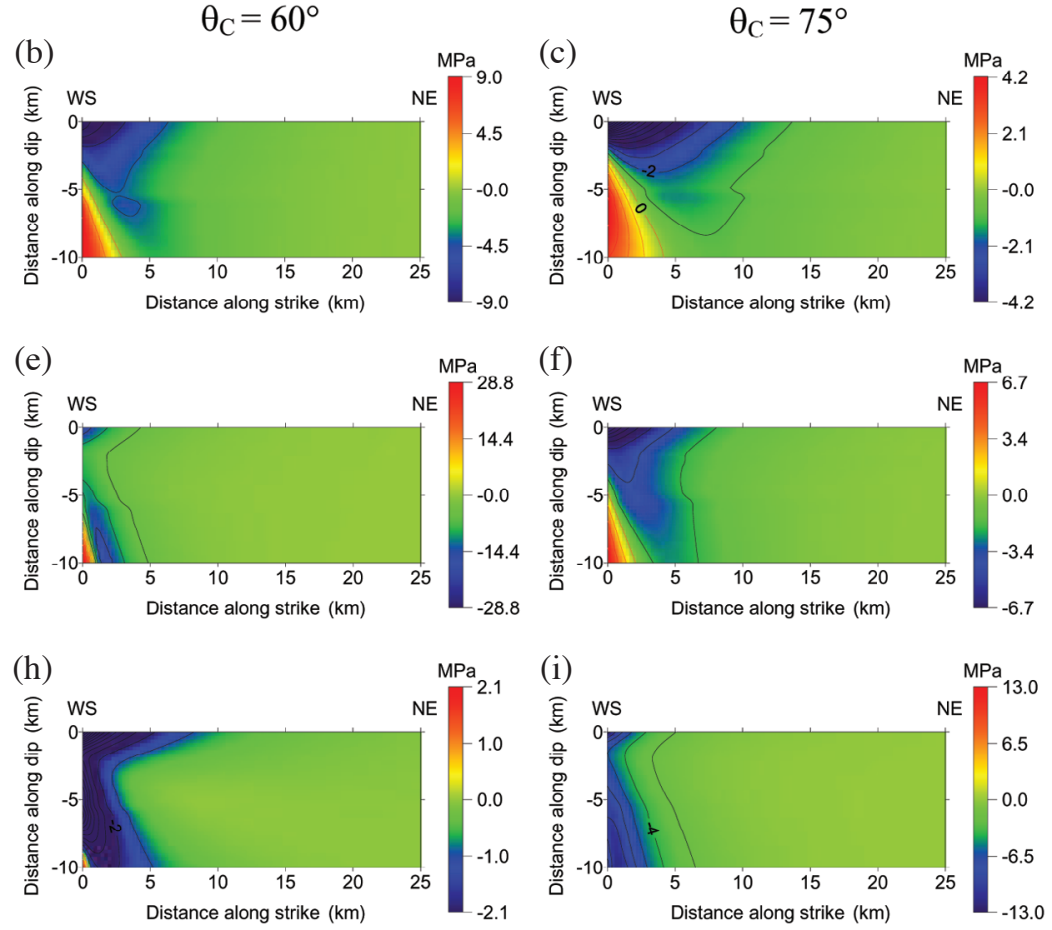

Fig. 2. The spatial distributions of $\triangle C F S$ in the Chinshan fault plane for $\theta_{\mathrm{C}}=45^{\circ}[(\mathrm{a}),(\mathrm{d})$, and (g) $], 60^{\circ}[(\mathrm{b}),(\mathrm{e})$, and (h) $]$, and $75^{\circ}[(\mathrm{c}),(\mathrm{f})$, and (i)], caused by a failure in the Shanchiao fault with $\theta_{\mathrm{S}}=45^{\circ}[(\mathrm{a}),(\mathrm{b})$, and (c) $], 60^{\circ}[(\mathrm{d}),(\mathrm{e})$, and (f) $]$, and $75^{\circ}[(\mathrm{g})$, (h), and (i) $]$ when $\phi_{\mathrm{S}}=-90^{\circ}$ and $\mathrm{D}_{\text {aves }}$ $=9.57 \mathrm{~m}$. The spatial distribution of $\triangle C F S$ in the Chinshan fault for $\theta_{\mathrm{C}}=45^{\circ}$ due to a failure in the Shanchiao fault with $\theta_{\mathrm{S}}=45^{\circ}$ when $\phi_{\mathrm{S}}=-90^{\circ}$ and $\mathrm{D}_{\text {aves }}=0.42 \mathrm{~m}$ is shown in $(\mathrm{j})$.

Figs. $2 \mathrm{a}-\mathrm{c}$ for $\theta_{\mathrm{S}}=45^{\circ}$; (2) Figs. $2 \mathrm{~d}-\mathrm{f}$ for $\theta_{\mathrm{S}}=60^{\circ}$; and (3) Figs. $2 \mathrm{~g}$ - $\mathrm{i}$ for $\theta_{\mathrm{S}}=75^{\circ}$. The regions with $\triangle C F S>0$ are displayed with red area and those with $\triangle C F S<0$ by blue ones. The maximum positive values of $\triangle C F S$ for $\theta_{\mathrm{C}}=45^{\circ}, 60^{\circ}$, and $75^{\circ}$, respectively, are: (1) $33.6,9.0$, and $4.2 \mathrm{MPa}$ when $\theta_{\mathrm{S}}=45^{\circ}$; (2) $9.2,28.8$, and $6.7 \mathrm{MPa}$ when $\theta_{\mathrm{S}}=60^{\circ}$; and (3) $6.5,2.1$, and $0 \mathrm{MPa}$ when $\theta_{\mathrm{S}}=75^{\circ}$. The distribution of $\triangle C F S$ in the Chinshan fault caused by a failure in the Shanchiao fault with the most possible average displacement of $D_{\text {aves }}=0.42 \mathrm{~m}$ when $\theta_{\mathrm{C}}=45^{\circ}, \theta_{\mathrm{S}}=45^{\circ}$, and $\phi_{\mathrm{s}}=-90^{\circ}$ is also computed and the result is displayed in Fig. 2j. The maximum positive values of $\triangle C F S$ are $1.48 \mathrm{MPa}$. Essentially, except for the values of $\triangle C F S$, the plot is similar to Fig. 2a with $\mathrm{D}_{\text {aves }}=9.57 \mathrm{~m}$, because $\triangle C F S$ is proportional to $\mathrm{D}_{\text {ave }}$. Hence, in the following computations only $\mathrm{D}_{\text {aves }}=$ $9.57 \mathrm{~m}$ for the Shanchiao fault and $\mathrm{D}_{\text {avec }}=14.07 \mathrm{~m}$ for the Chinshan fault evaluated, respectively, from Eq. (1) are taken into account.
Considering the case that the Chinshan fault that is also a purely normal fault with $\phi_{\mathrm{C}}=-90^{\circ}$ first breaks, the spatial distributions of $\triangle C F S$ for $\theta_{\mathrm{S}}=45^{\circ}, 60^{\circ}$, and $75^{\circ}$ in the Shanchiao fault plane caused by the former, with $\theta_{\mathrm{C}}=45^{\circ}, 60^{\circ}$, and $75^{\circ}$ and $D_{\text {avec }}=14.07 \mathrm{~m}$ are shown in Fig. 3: (1) Figs. 3a - c for $\theta_{\mathrm{C}}=45^{\circ}$; (2) Figs. $3 \mathrm{~d}$ - $\mathrm{f}$ for $\theta_{\mathrm{C}}=60^{\circ}$; and (3) Figs. $3 \mathrm{~g}$ - $\mathrm{i}$ for $\theta_{\mathrm{C}}=75^{\circ}$. The maximum positive values of $\triangle C F S$ for $\theta_{\mathrm{S}}=45^{\circ}, 60^{\circ}$, and $75^{\circ}$, respectively, are: (1) $321.1,0.9$, and $0.5 \mathrm{MPa}$ when $\theta_{\mathrm{C}}=45^{\circ}$; (2) $5.7,0$, and $0.9 \mathrm{MPa}$ when $\theta_{\mathrm{C}}=$ $60^{\circ}$; and (3) 4.4, 0 , and $0 \mathrm{MPa}$ when $\theta_{\mathrm{C}}=75^{\circ}$.

\subsection{Varied Slip Directions of Faulting}

It is also significant to understand what might occur when faulting is not purely normal faulting for the Shanchiao fault and the Chinshan fault. First, static stress changes in the Chinshan fault caused by a failure in the Shanchiao fault with $\theta_{\mathrm{S}}=45^{\circ}, 60^{\circ}$, and $75^{\circ}$ are evaluated. The spatial 


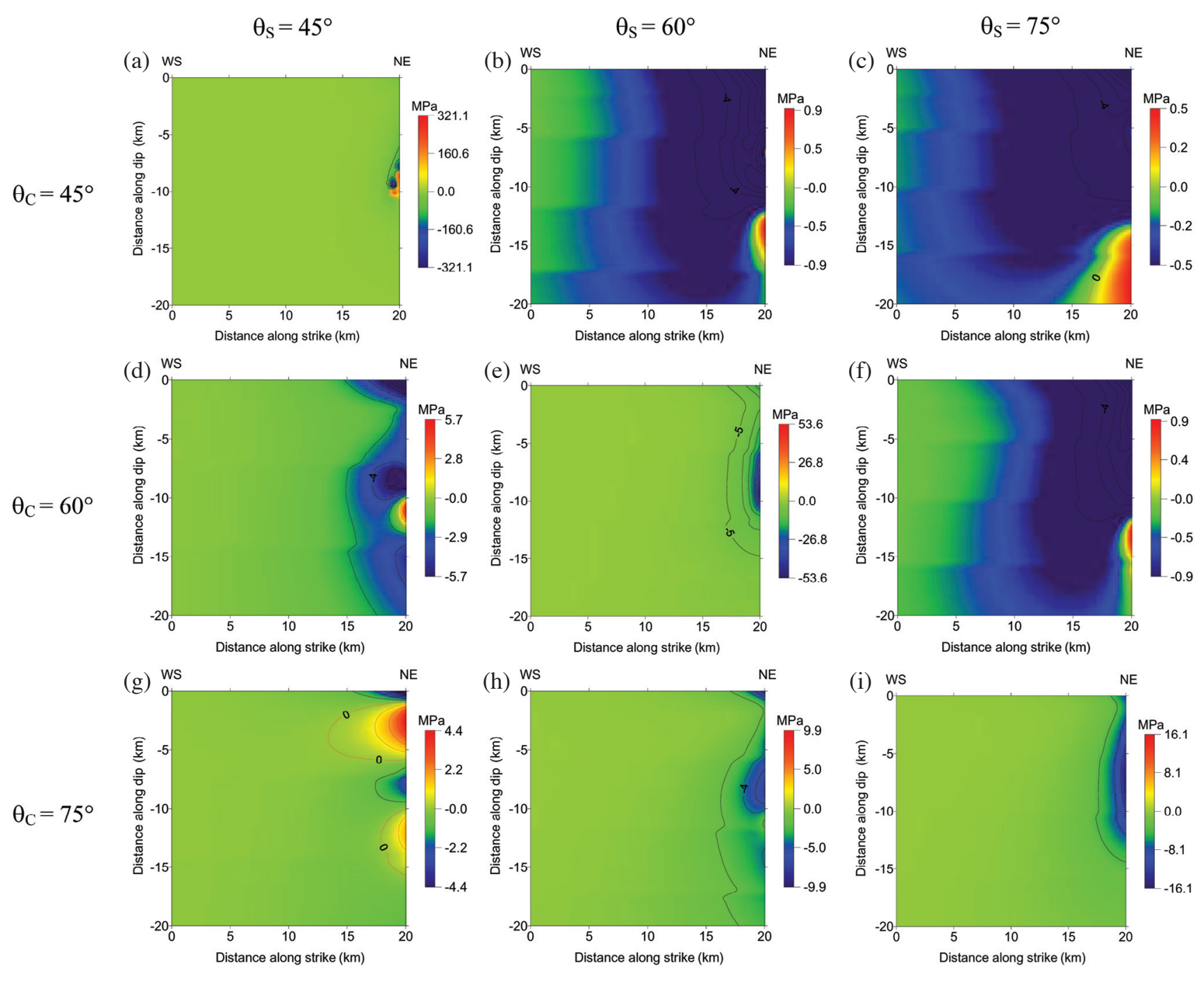

Fig. 3. The spatial distributions of $\triangle C F S$ in the Shanchiao fault plane for $\theta_{\mathrm{S}}=45^{\circ}[(\mathrm{a}),(\mathrm{d})$, and $(\mathrm{g})], 60^{\circ}\left[(\mathrm{b}),(\mathrm{e})\right.$, and (h)], and $75^{\circ}[(\mathrm{c}),(\mathrm{f})$, and (i)], caused by a failure in the Chinshan fault with $\theta_{\mathrm{C}}=45^{\circ}\left[(\mathrm{a}),(\mathrm{b})\right.$, and (c)], $60^{\circ}[(\mathrm{d}),(\mathrm{e})$, and (f) $]$, and $75^{\circ}[(\mathrm{g}),(\mathrm{h})$, and (i) $]$ when $\phi_{\mathrm{C}}=-90^{\circ}$ and $\mathrm{D}_{\text {aveC }}=14.07 \mathrm{~m}$.

distributions of $\triangle C F S$ in the Chinshan fault with $\theta_{\mathrm{C}}=45^{\circ}$, $60^{\circ}$, and $75^{\circ}$ are shown in Fig. 4 for $\phi_{\mathrm{S}}=-45^{\circ}$ and Fig. 5 for $\phi_{\mathrm{S}}=-135^{\circ}$ when $\mathrm{D}_{\text {aves }}=9.57 \mathrm{~m}$. In Fig. 4, the maximum positive values of $\triangle C F S$ for $\theta_{\mathrm{C}}=45^{\circ}$ (Figs. $4 \mathrm{a}-\mathrm{c}$ ), $60^{\circ}$ (Figs. $4 \mathrm{~d}$ - f), and $75^{\circ}$ (Figs. $4 \mathrm{~g}$ - i), respectively, are: (1) $12.1,1.1$, and $0.4 \mathrm{MPa}$ when $\theta_{\mathrm{S}}=45^{\circ}$; (2) $30.9,5.4$, and $0.7 \mathrm{MPa}$ when $\theta_{\mathrm{S}}=60^{\circ}$; and (3) $12.2,18.6$, and $3.3 \mathrm{MPa}$ when $\theta_{\mathrm{S}}=75^{\circ}$. In Fig. 5, the maximum positive values of $\triangle C F S$ for $\theta_{\mathrm{C}}=45^{\circ}$ (Figs. $5 \mathrm{a}-\mathrm{c}$ ), $60^{\circ}$ (Figs. $5 \mathrm{~d}$ - f), and $75^{\circ}$ (Figs. 5g - i), respectively, are: (1) 59.1, 15.2, and 7.6 MPa when $\theta_{\mathrm{S}}=45^{\circ}$; (2) $5.9,46.3$, and $11.4 \mathrm{MPa}$ when $\theta_{\mathrm{S}}=60^{\circ}$; and (3) $3.0,0$, and $0 \mathrm{MPa}$ when $\theta_{\mathrm{S}}=75^{\circ}$.

Similarly, static stress changes in the Shanchiao fault caused by a failure in the Chinshan fault with $\theta_{\mathrm{C}}=45^{\circ}, 60^{\circ}$, and $75^{\circ}$ are evaluated. The spatial distributions of $\triangle C F S$ in the Shanchiao fault for $\theta_{\mathrm{S}}=45^{\circ}, 60^{\circ}$, and $75^{\circ}$ are shown in
Fig. 6 when $\phi_{C}=-45^{\circ}$ and in Fig. 7 when $\phi_{C}=-135^{\circ}$, both with $D_{\text {aveC }}=14.07 \mathrm{~m}$. In Fig. 6, the maximum positive values of $\triangle C F S$ for $\theta_{S}=45^{\circ}$ (Figs. 6a - c), $60^{\circ}$ (Figs. 6d - f), and $75^{\circ}$ (Figs. $6 \mathrm{~g}$ - i), respectively, are: (1) 455.3, 16.4, and 6.2 MPa when $\theta_{\mathrm{C}}=45^{\circ}$; (2) 0,0 , and $2.8 \mathrm{MPa}$ when $\theta_{\mathrm{C}}=$ $60^{\circ}$; and (3) 2.8, 0 , and $0 \mathrm{MPa}$ when $\theta_{\mathrm{C}}=75^{\circ}$. In Fig. 7, the maximum positive values of $\triangle C F S$ for $\theta_{\mathrm{S}}=45^{\circ}$ (Figs. 7a - c), $60^{\circ}$ (Figs. $7 \mathrm{~d}$ - f), and $75^{\circ}$ (Figs. $7 \mathrm{~g}$ - i), respectively, are: (1) 77.0, 5.5, and 2.9 MPa when $\theta_{\mathrm{C}}=45^{\circ}$; (2) 13.3, 5.6, and 5.8 MPa when $\theta_{\mathrm{C}}=60^{\circ}$; and (3) $6.4,5.4$, and $3.3 \mathrm{MPa}$ when $\theta_{\mathrm{C}}=75^{\circ}$.

\section{DISCUSSION}

The failure of a fault must be controlled by the total stress exerted on and yielding strength of the fault. Hence, 


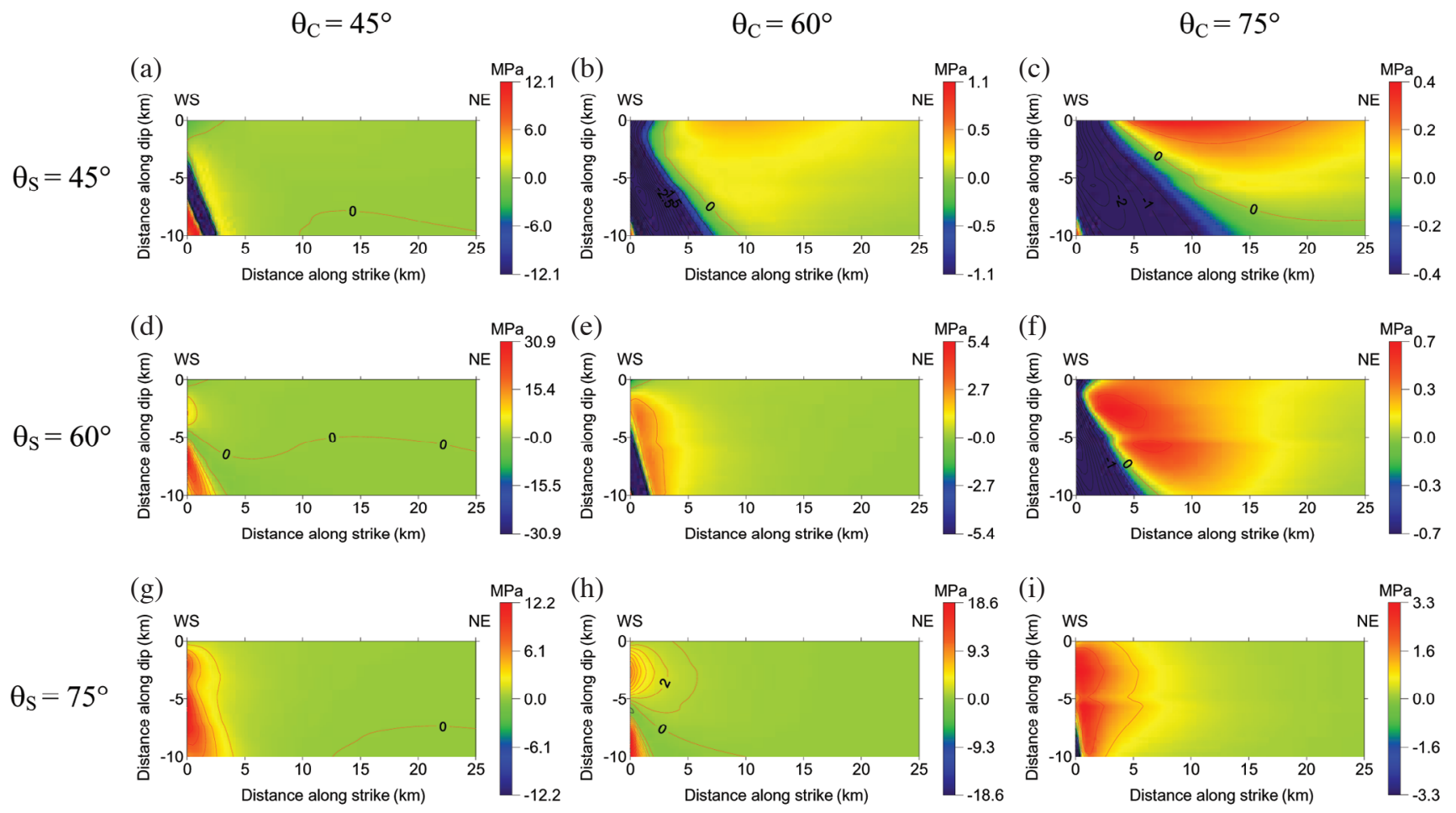

Fig. 4. The spatial distributions of $\triangle C F S$ in the Chinshan fault for $\theta_{\mathrm{C}}=45^{\circ}[(\mathrm{a}),(\mathrm{d})$, and $(\mathrm{g})], 60^{\circ}\left[(\mathrm{b}),(\mathrm{e})\right.$, and (h)], and $75^{\circ}[(\mathrm{c}),(\mathrm{f})$, and (i)], caused by a failure in the Shanchiao fault with $\theta_{\mathrm{S}}=45^{\circ}[(\mathrm{a}),(\mathrm{b})$, and (c) $], 60^{\circ}[(\mathrm{d}),(\mathrm{e})$, and (f) $]$, and $75^{\circ}[(\mathrm{g}),(\mathrm{h})$, and (i) $]$ when $\phi_{\mathrm{S}}=-45^{\circ}$ and $\mathrm{D}_{\text {aves }}=$ $9.57 \mathrm{~m}$.
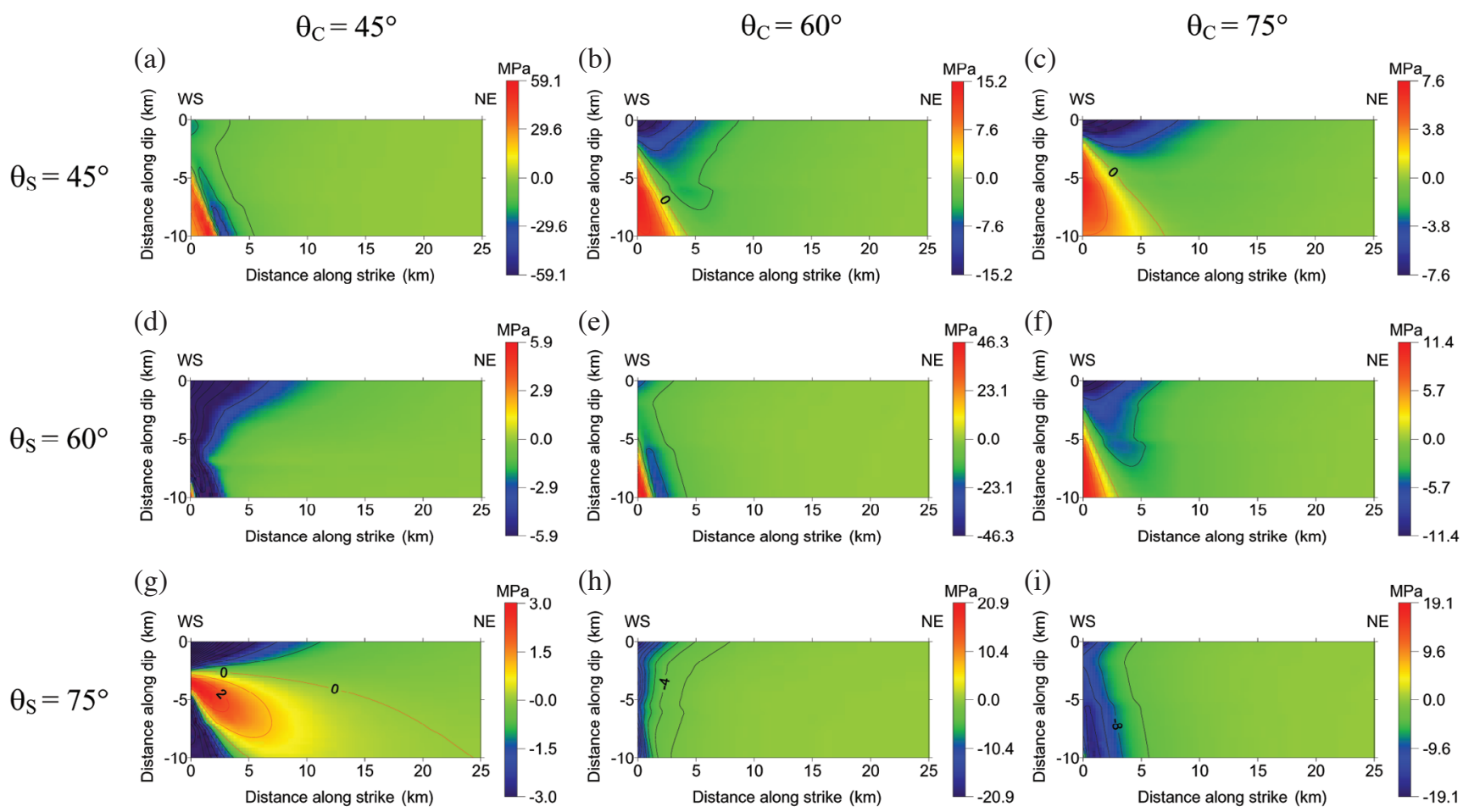

Fig. 5. The spatial distributions of $\triangle C F S$ in the Chinshan fault for $\theta_{\mathrm{C}}=45^{\circ}[(\mathrm{a}),(\mathrm{d})$, and (g) $], 60^{\circ}\left[(\mathrm{b}),(\mathrm{e})\right.$, and (h)], and $75^{\circ}[(\mathrm{c})$, (f), and (i)], caused by a failure in the Shanchiao fault with $\theta_{\mathrm{S}}=45^{\circ}[(\mathrm{a}),(\mathrm{b})$, and (c) $], 60^{\circ}\left[(\mathrm{d}),(\mathrm{e})\right.$, and (f)], and $75^{\circ}[(\mathrm{g}),(\mathrm{h})$, and (i) $]$ when $\phi_{\mathrm{S}}=-135^{\circ}$ and $\mathrm{D}_{\text {aves }}=$ $9.57 \mathrm{~m}$. 
it is noted that the existence of the positive $\triangle C F S$ on a fault plane in the following simulations shows the possibility of occurrence of ruptures and cannot give a definite prediction or forecasting of ruptures on a fault as mentioned by Utkucu et al. (2003) and Chang and Wang (2006). Nevertheless, the simulation results together other information can help us to further estimate a seismic hazard. However, it is certain that the presence of the negative $\triangle C F S$ would decrease the seismicity rate (Ma et al. 2005), thus preventing rupture.

Figure 2 shows that the spatial distribution of $\triangle C F S$ in the Chinshan fault caused by a failure in the Shanchiao fault obviously depends upon $\theta_{\mathrm{C}}$ and $\theta_{\mathrm{S}}$. When $\theta_{\mathrm{S}}=45^{\circ}$, the maximum magnitude of the positive $\triangle C F S$ decreasing monotonously with increasing $\theta_{\mathrm{C}}$. When $\theta_{\mathrm{S}}=60^{\circ}$, the maximum magnitude of the positive $\triangle C F S$ increases first and then decreases with increasing $\theta_{\mathrm{C}}$. When $\theta_{\mathrm{S}}=75^{\circ}$, the maximum magnitude of the positive $\triangle C F S$ decreases first and then increases with increasing $\theta_{\mathrm{C}}$. Results infer that a failure of a less steep Shanchiao fault is capable of triggering a less steep Chinshan fault than a steeper Chinshan fault. An extreme case is that the dip angles of the two faults are both $75^{\circ}$, the $\triangle C F S$ values in the Chinshan fault caused by the Shanchiao fault are all negative and means the Chinshan fault with $\theta_{\mathrm{C}}=75^{\circ}$ cannot be triggered by a failure on the Shanchiao fault plane with $\theta_{S}=75^{\circ}$. Figure 2 also shows that it is easier to trigger ruptures starting from the south than from the north of the Chinshan fault because the positive $\triangle C F S$ spreads at the south and decays to the north. When $\theta_{\mathrm{S}}=45^{\circ}$ and $60^{\circ}$, the areas with $\triangle C F S>0$ are all located at the left down corner of the Chinshan fault, and negative $\triangle C F S$ areas spread widely over the fault plane. Therefore, for these cases, the Chinshan fault might break only locally.
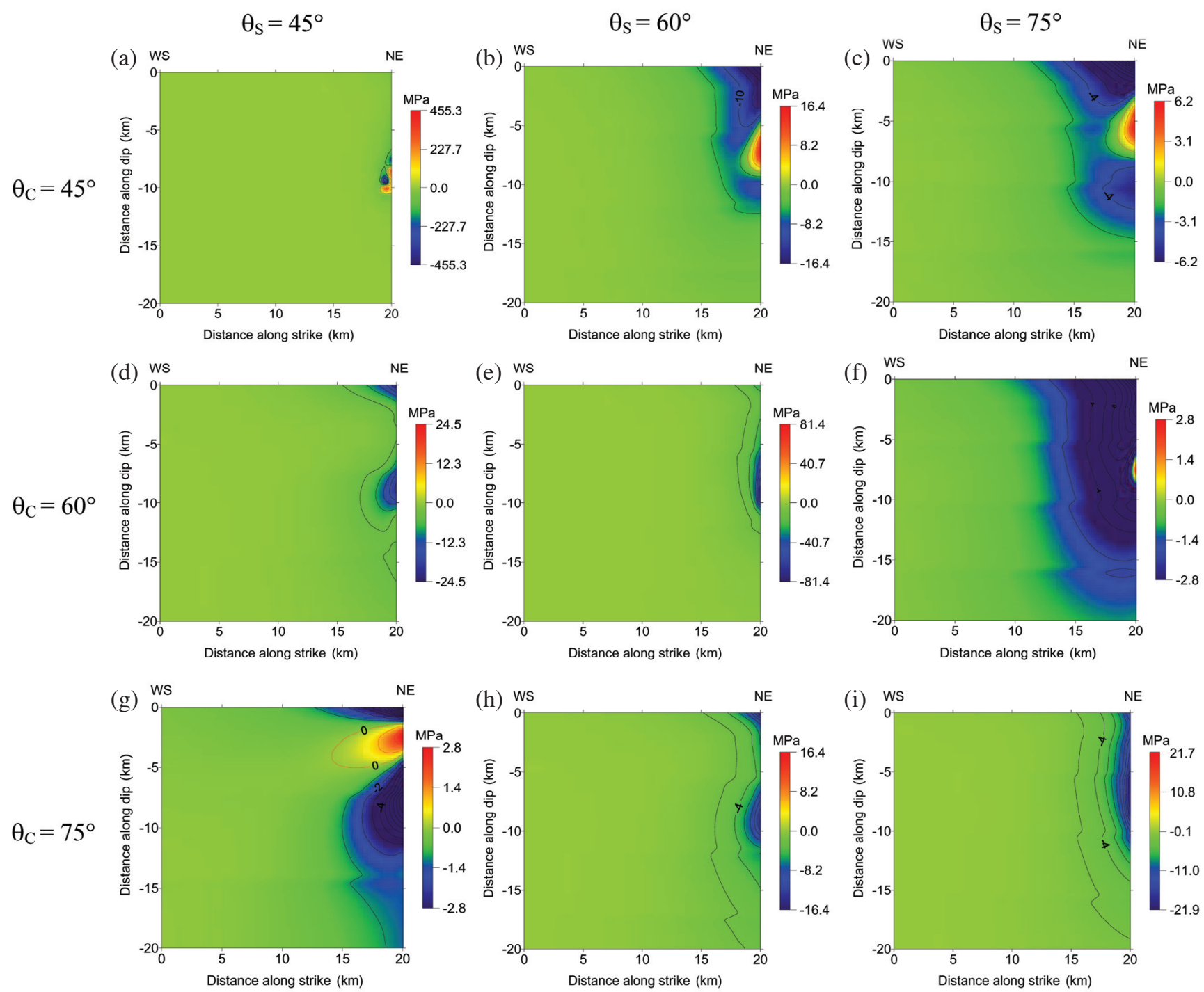

Fig. 6. The spatial distributions of $\triangle C F S$ in the Shanchiao fault for $\theta_{\mathrm{S}}=45^{\circ}[(\mathrm{a}),(\mathrm{d})$, and (g) $], 60^{\circ}\left[(\mathrm{b})\right.$, (e), and (h)], and $75^{\circ}$ [(c), (f), and (i)], caused by a failure in the Chinshan fault with $\theta_{\mathrm{C}}=45^{\circ}[(\mathrm{a}),(\mathrm{b})$, and (c) $], 60^{\circ}[(\mathrm{d}),(\mathrm{e})$, and (f) $]$, and $75^{\circ}[(\mathrm{g}),(\mathrm{h})$, and (i) $]$ when $\phi_{\mathrm{C}}=-45^{\circ}$ and $\mathrm{D}_{\text {aveC }}=$ $14.07 \mathrm{~m}$. 


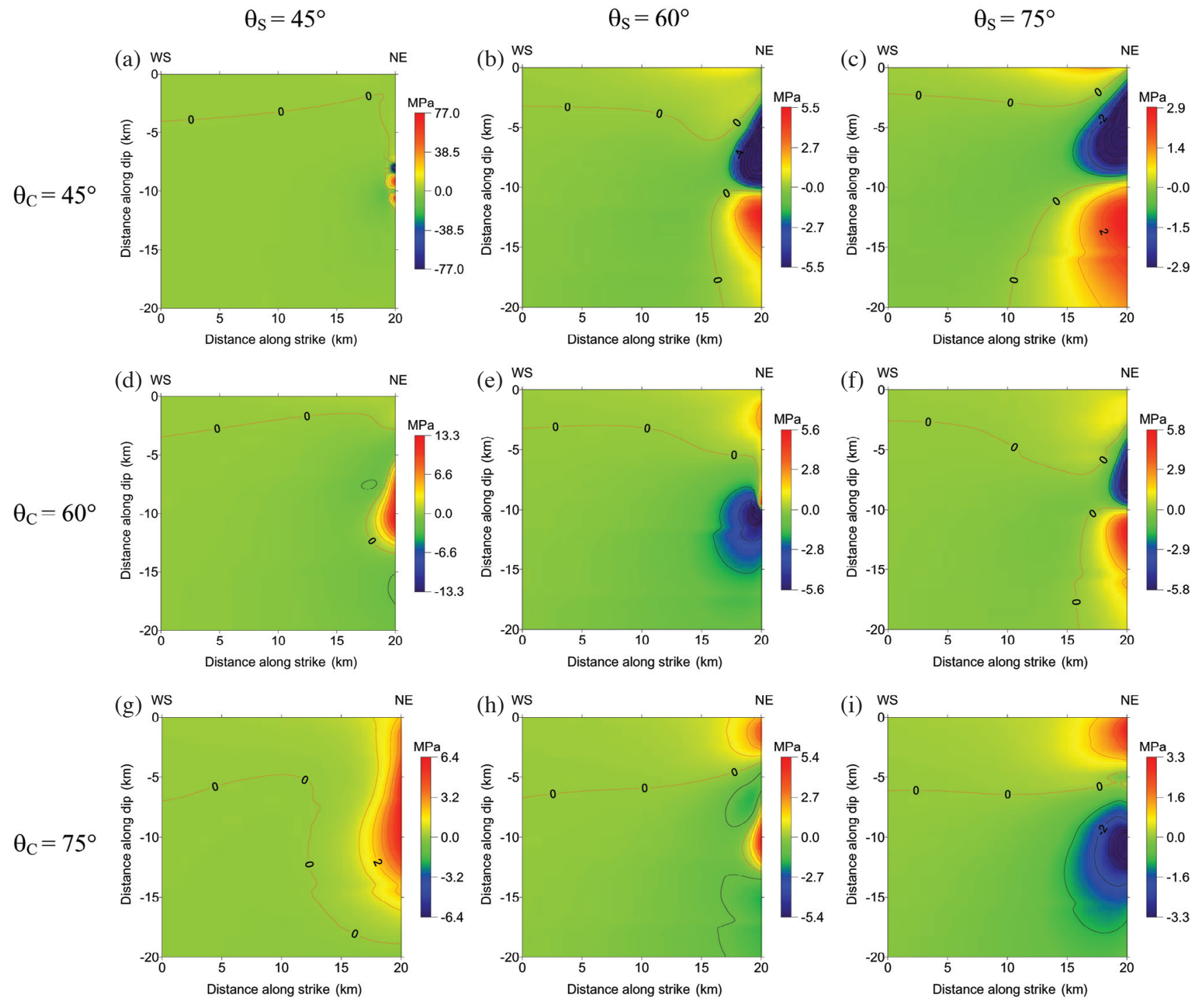

Fig. 7. The spatial distributions of $\triangle C F S$ in the Shanchiao fault for $\theta_{\mathrm{S}}=45^{\circ}[(\mathrm{a}),(\mathrm{d})$, and $(\mathrm{g})], 60^{\circ}\left[(\mathrm{b}),(\mathrm{e})\right.$, and (h)], and $75^{\circ}[(\mathrm{c}),(\mathrm{f})$, and (i)], caused by a failure in the Chinshan fault with $\theta_{\mathrm{C}}=45^{\circ}[(\mathrm{a}),(\mathrm{b})$, and (c) $], 60^{\circ}[(\mathrm{d}),(\mathrm{e})$, and (f) $]$, and $75^{\circ}[(\mathrm{g}),(\mathrm{h})$, and (i) $]$ when $\phi_{\mathrm{C}}=-135^{\circ}$ and $\mathrm{D}_{\text {avec }}$ $=14.07 \mathrm{~m}$.

Local rupture would also happen locally for the case with $\theta_{\mathrm{S}}=75^{\circ}$ and $\theta_{\mathrm{C}}=60^{\circ}$. When $\theta_{\mathrm{S}}=75^{\circ}$ and $\theta_{\mathrm{C}}=45^{\circ}$, the positive $\triangle C F S$ areas spread widely over the fault plane, so rupture would take place anywhere on the fault plane.

Figure 3 shows the $\theta_{\mathrm{C}^{-}}$and $\theta_{\mathrm{S}^{-}}$-dependence of the spatial distribution of $\triangle C F S$ in the Shanchiao fault caused by a failure on the Chinshan fault plane. When $\theta_{C}=45^{\circ}$, the maximum magnitude of the positive $\triangle C F S$ decreases monotonously with increasing $\theta_{\mathrm{S}}$, but the area of the positive $\triangle C F S$ increases with $\theta_{\mathrm{s}}$. Figure $3 \mathrm{a}$ shows that although the possibility of triggering rupture is low on most of the fault plane, a failure could still occur on a small area with $\triangle C F S>321.1 \mathrm{MPa}$. In general, the possibility of triggering increases with decreasing $\theta_{\mathrm{C}}$. When $\theta_{\mathrm{C}}=60^{\circ}$, the maximum magnitude of the positive $\triangle C F S$ decreases first and then increases with increasing $\theta_{\mathrm{s}}$, and the areas of the positive $\triangle C F S$ appear merely in a very small part or are totally absent in the Shanchiao fault. Obviously, it is not appropriate for triggering rupture in the Shanchiao fault. When $\theta_{\mathrm{C}}=75^{\circ}$, the maximum magnitude of the positive $\triangle C F S$ changes from 4.4 MPa for $\theta_{\mathrm{S}}=45^{\circ}$ to $0 \mathrm{MPa}$ for $\theta_{\mathrm{S}}=60^{\circ}$ and $75^{\circ}$. This means no event can be triggered in the Shanchiao fault for these conditions. Figure 3 also shows that when the Shanchiao fault is triggered, rupture more easily occurs starting from the north than from the south of the fault.

Figures 4 and 5 show that the spatial distributions of $\triangle C F S$ in the Chinshan fault caused by a failure in the Shanchiao fault with two extreme rake angles of normal fault, i.e., $\phi_{\mathrm{S}}=-45^{\circ}$ and $-135^{\circ}$. In Fig. 4 , the distribution of $\triangle C F S$ in the Chinshan fault depends upon $\theta_{\mathrm{C}}$ and $\theta_{\mathrm{S}}$. When $\theta_{\mathrm{S}}=$ 
$45^{\circ}$ and $60^{\circ}$, the maximum magnitude of the positive $\triangle C F S$ decreases monotonously with increasing $\theta_{\mathrm{C}}$. When $\theta_{\mathrm{S}}=75^{\circ}$, the maximum magnitude of the positive $\triangle C F S$ increases first and then decreases with increasing $\theta_{\mathrm{C}}$. Results imply that a failure in a steeper Shanchiao fault is more capable of triggering the Chinshan fault. The areas with $\triangle C F S>0$ spread widely in the Chinshan fault and also increase with $\theta_{\mathrm{s}}$. This means that it is also easier to trigger the Chinshan fault due to a steeper Shanchiao fault.

Figure 5 shows the $\theta_{\mathrm{C}^{-}}$and $\theta_{\mathrm{s}^{-}}$-dependence of the spatial distribution of $\triangle C F S$ in the Chinshan fault caused by a failure in the Shanchiao fault. When $\theta_{\mathrm{S}}=45^{\circ}$, the maximum magnitude of the positive $\triangle C F S$ decreases monotonously with increasing $\theta_{\mathrm{C}}$. When $\theta_{\mathrm{S}}=60^{\circ}$, the maximum magnitude of the positive $\triangle C F S$ increases first and then decreases with increasing $\theta_{\mathrm{C}}$. When $\theta_{\mathrm{S}}=75^{\circ}$, the maximum magnitude of the positive $\triangle C F S$ decreases from $3 \mathrm{MPa}$ for $\theta_{\mathrm{C}}=45^{\circ}$ to zero for both $\theta_{\mathrm{C}}=60^{\circ}$ and $75^{\circ}$. When $\theta_{\mathrm{S}}=45^{\circ}$ and $60^{\circ}$, the area with the positive $\triangle C F S$ extends from the left-side, lower corner upwards when $\theta_{\mathrm{C}}$ is increased and implies that it is easier to initiate a break at depths in a less steep Chinshan fault than in a steep Chinshan fault. Meanwhile, the break can only appear in a small part of the fault plane. When $\theta_{\mathrm{C}}=60^{\circ}$ and $75^{\circ}$ under $\theta_{\mathrm{S}}=75^{\circ}$, not any area with the positive $\triangle C F S$ in the Chinshan fault can be found. This means that rupture cannot be triggered in the Chinshan fault under these conditions. Except for the cases with $\theta_{\mathrm{S}}=$ $75^{\circ}$, the positive $\triangle C F S$ area increases with $\theta_{\mathrm{C}}$ and implies that except for these particular cases, it is easier to trigger a break in a steep Chinshan fault than in a less steep Chinshan fault due to a failure in the Shanchiao fault. When $\theta_{\mathrm{S}}=75^{\circ}$ and $\theta_{\mathrm{C}}=45^{\circ}$, there is a moderate-sized positive $\triangle C F S$ area, with the maximum value of $3 \mathrm{MPa}$, on the left side of the Chinshan fault.

Figures 6 and 7 show that the spatial distributions of $\triangle C F S$ in the Shanchiao fault caused by a failure in the Chinshan fault with two extreme rake angles of normal fault, i.e., $\phi_{\mathrm{C}}=-45^{\circ}$ (in Fig. 6) and $-135^{\circ}$ (in Fig. 7). Obviously, the distribution of $\triangle C F S$ varies with both $\theta_{\mathrm{C}}$ and $\theta_{\mathrm{S}}$. In Fig. 6 for $\phi_{\mathrm{C}}=-45^{\circ}$, the maximum positive $\triangle C F S$ decreases monotonously with increasing $\theta_{\mathrm{S}}$ and the areas of the maximum values of positive and negative $\triangle C F S$ increase with $\theta_{\mathrm{S}}$ when $\theta_{\mathrm{C}}=45^{\circ}$. When $\theta_{\mathrm{C}}=60^{\circ}$, there is only a very small area with positive $\triangle C F S$ in the Shanchiao fault with $\theta_{\mathrm{S}}=$ $75^{\circ}$. So, there would be ruptures in a small part of the Shanchiao fault. Under other conditions $\left(\theta_{\mathrm{S}}=45^{\circ}\right.$ and $\left.60^{\circ}\right)$, there are no positive $\triangle C F S$ areas in the Shanchiao fault. Hence, it seems unable to trigger an event in this fault under these conditions. When $\theta_{\mathrm{C}}=75^{\circ}$, except for $\theta_{\mathrm{S}}=45^{\circ}$ there is not any area with positive $\triangle C F S$ in the Shanchiao fault, so that this fault cannot be triggered when its dip angle is greater than $60^{\circ}$.

In Fig. 7 for $\phi_{\mathrm{C}}=-135^{\circ}$, the maximum positive $\triangle C F S$ decreases monotonously with increasing $\theta_{\mathrm{S}}$, except for the case with $\theta_{\mathrm{S}}=60^{\circ}$ and $\theta_{\mathrm{C}}=60^{\circ}$. This implies that a failure in the Chinshan fault is more capable of increasing stresses in a less steep Shanchiao fault. Such a capability decreases when either of the two faults becomes steeper. The case with $\theta_{\mathrm{C}}=45^{\circ}$ and $\theta_{\mathrm{S}}=45^{\circ}$ is the optimum one for such triggering, because the stress increase in the latter is higher than $77 \mathrm{MPa}$. When $\theta_{\mathrm{C}}=45^{\circ}$, both the positive and negative $\triangle C F S$ areas increase with $\theta_{\mathrm{s}}$. When $\theta_{\mathrm{S}}=45^{\circ}$, both the positive $\triangle C F S$ area increases with $\theta_{\mathrm{C}}$. For other cases, the positive $\triangle C F S$ area varies with both $\theta_{\mathrm{C}}$ and $\theta_{\mathrm{s}}$. The area with positive $\triangle C F S$ extends more or less from the depths to the shallow depths of the fault plane when $\theta_{\mathrm{C}}$ is increased. Hence, it is easier to trigger ruptures in the topmost surface for a steeper Chinshan fault than a less steep one.

In Figs. 4, 2 and 5, the values of $\phi_{\mathrm{S}}$ are $-45^{\circ},-90^{\circ}$ and $-135^{\circ}$, respectively. Results show that when $\theta_{\mathrm{S}}=45^{\circ}$, the maximum magnitude of the positive $\triangle C F S$ increases with $\phi_{\mathrm{S}}$, and when $\theta_{\mathrm{S}}=45^{\circ}$, the maximum magnitude of the positive $\triangle C F S$ increases with $\phi_{\mathrm{s}}$. From the distribution of the positive $\triangle C F S$, the capability of triggering the Chinshan fault depends upon $\phi_{\mathrm{s}}$ : the largest for $\phi_{\mathrm{S}}=-45^{\circ}$, moderate for $\phi_{\mathrm{S}}=-90^{\circ}$, and the smallest for $\phi_{\mathrm{S}}=-135^{\circ}$. Meanwhile, the larger the rake toward the striking direction of the to-betriggered fault, the higher the capability of triggering.

In Figs. 6, 3 and 7, the values of $\phi_{C}$ are $-45^{\circ},-90^{\circ}$ and $-135^{\circ}$, respectively. Results show that the spatial distribution of $\triangle C F S$ in the Shanchiao fault almost depends upon $\phi_{\mathrm{C}}$ and the area with positive $\triangle C F S$ increases with $\phi_{\mathrm{C}}$. From the distribution of the positive $\triangle C F S$, the capability of triggering the Shanchiao fault depends upon $\phi_{\mathrm{C}}$ : the largest for $\phi_{\mathrm{C}}=-135^{\circ}$, moderate for $\phi_{\mathrm{C}}=-90^{\circ}$, and the smallest for $\phi_{\mathrm{C}}=-45^{\circ}$. Meanwhile, the larger the rake toward the striking direction of to-be-triggered fault, the higher the capability of triggering.

\section{CONCLUSIONS}

In this study, interaction between the Shanchiao and Chinshan faults in the Taipei metropolitan area is studied on the basis of stress transfer from a fault, which breaks first, to the other. From the relationships of average displacement versus fault length inferred by Wells and Coppersmith (1994), the ranges of average displacement, $D_{\text {ave }}$, of the two faults are evaluated. The spatial distributions of $\triangle C F S$ on the Chinshan fault plane, with dip angles of $45^{\circ}, 60^{\circ}$, and $75^{\circ}$ due to a failure in the Shanchiao fault, with dip angles of $45^{\circ}, 60^{\circ}$, and $75^{\circ}$, are calculated. Results show that the Chinshan fault can be more likely triggered by a failure of the Shanchiao fault, because there are more non-triggered cases for the Shanchiao fault than the Chinshan fault. In addition, when the rake angle of the ruptured fault is toward the direction of the to-be-triggered fault, the capability of triggering is increased.

Since the maximum positive $\triangle C F S$ exists at the north 
part of the Shanchiao fault, ruptures propagate from north to south. But the maximum positive $\triangle C F S$ exists on the south part of the Chinshan fault, ruptures propagate from south to north. From the spatial distributions of the $\triangle C F S$ on the two fault planes, the areas with the positive $\triangle C F S$ are always larger on the steeper fault rupture (with $\phi_{\mathrm{S}}=-45^{\circ}$ and $\phi_{\mathrm{C}}=$ $-135^{\circ}$ ) than the less steep ones. This seems to indicate that when the two faults have larger dip angles and the direction of rupture in a fault points to the other, there would be a higher possibility of triggering the other fault.

Acknowledgements The authors would like to thank Dr. $\mathrm{R}$. Wang for providing the software and offering generous discussions. This study was financially supported by Academia Sinica (Taipei) under Grant No. AS-94-TP-A08.

\section{REFERENCES}

Bonilla, M. G., 1977: Summary of Quarternary faulting and elevation changes in Taiwan. Mem. Geol. Soc. China, 2, 43-46.

CGS (Central Geological Survey), 1999: Subsurface Geology and Engineering Environment of Taipei Basin. Special Pub. 11, Central Geological Survey, MOEA, Taipei, Taiwan, ROC, 406 pp.

CGS (Central Geological Survey), 2000: An Introduction to The Active Faults of Taiwan. $2^{\text {nd }}$ edition, Special Pub. 13, Central Geological Survey, MOEA, Taipei, Taiwan, ROC, $122 \mathrm{pp}$

CGS (Central Geological Survey), 2007: Active Faults of Northern Taiwan. Special Pub. 19, Central Geological Survey, MOEA, Taipei, Taiwan, ROC, 130 pp.

CGS (Central Geological Survey), 2008: The secret worry of the Taipei basin - The Shanchiao fault, http://www. moeacgs.gov.tw/info/view.jsp?info=264. (in Chinese)

Chan, Y. C., J. C. Lee, J. K. Liu, and D. Y. Cheng, 2005a: Surveys and monitoring of special geological hazards in the Taipei metropolitan area: High-precision airborne LIDAR mapping, topography, and analysis of structures. Open-File Rept., Central Geol. Surv., MOEA, Taipei, Taiwan, ROC, 143 pp. (in Chinese)

Chan, Y. C., J. C. Lee, R. F. Chen, K. C. Chang, J. K. Liu, W. C. Hsu, J. C. Hu, W. S. Chen, C. C. Yang, Y. G. Chen, D. Y. Cheng, S. Tsao, and Y. C. Hsieh, 2005b: Airborne LIDAR mapping of the metropolitan Taipei area: Current status and progress. Proc. Symp. on Volcanic Activity and the Shanchiao Fault, Central Geol. Surv., MOEA, Taipei, Taiwan, ROC, 87-101.

Chang, H. C., C. W. Lin, M. M. Chen, and S. T. Lu, 1998: An Introduction to the Active Faults of Taiwan, Explanatory Text of the Active Fault Map of Taiwan SCALE 1 : 55000, Open-File Rept., Central Geol. Surv., MOEA, Taipei, Taiwan, ROC, 103 pp. (in Chinese)

Chang, S. H. and W. H. Wang, 2006: Mechanical proper- ties, slip and nucleation of the 1999 Chia-Yi earthquake: The question of static stress influence from the 1999 Chi-Chi earthquake. Terr. Atmos. Ocean. Sci., 17, 331-343.

Chen, C. H., T. L. Teng, and Y. C. Gung, 1998: Ten-second Love-wave propagation and strong ground motions in Taiwan. J. Geophys. Res., 103, 21253-21273.

Chen, C. T., J. C. Hu, C. Y. Lu, J. C. Lee, and Y. C. Chan, 2007a: Thirty-year land elevation change from subsidence to uplift following the termination of groundwater pumping and its geological implications in the Metropolitan Taipei Basin, Northern Taiwan. Eng. Geol., 95, 30-47, doi: 10.1016/j.enggeo.2007.09.001. [Link]

Chen, K. C., W. G. Huang, and J. H. Wang, 2007b: Relationships among magnitudes and seismic moment of earthquakes in the Taiwan region. Terr. Atmos. Ocean. Sci., 18, 951-973, doi: 10.3319/TAO.2007.18.5.951(T). [Link]

Chen, K. C., B. S. Huang, W. G. Huang, J. H. Wang, K. H. Kim, S. J. Lee, Y. C. Lai, S. Tsao, and C. H. Chen, 2010: A blind normal fault beneath the Taipei basin in northern Taiwan. Terr. Atmos. Ocean. Sci., 21, 495502, doi: 10.3319/TAO.2010.01.25.01(TH). [Link]

Hsu, H., 1983: Source materials on the history of natural disasters in Ching Taiwan. Hazards Mitigation S\&T Report, 72-01, 5-6.

Hsu, M. T., 1961: Seismicity of Taiwan (Formosa). Bull. Earthq. Res. Inst., 39, 831-847.

Huang, S. Y., C. M. Rubin, Y. G. Chen, H. C. Liu, and C. L. Chiu, 2003: Prehistoric earthquakes along the Shanchiao fault, Taipei Basin, Northern Taiwan. Eos, Trans., AGU, 84, Fall Meeting, Suppl., Abstract, San Francisco, CA.

Kim, K. H., C. H. Chang, K. F. Ma, J. M. Chiu, and K. C. Chen, 2005: Modern seismic observations in the Tatun volcano region of northern Taiwan: Seismic/volcanic hazard adjacent to the Taipei Metropolitan area. Terr. Atmos. Ocean. Sci., 16, 579-594.

King, G. C. P., R. S. Stein, and J. Lin, 1994: Static stress changes and the triggering of earthquakes. Bull. Seismol. Soc. Am., 84, 935-953.

Lin, C. H., 2002: Active continental subduction and crustal exhumation: The Taiwan orogeny. Terr. Nova, 14, 281-287.

Lin, C. H., 2005: Seismicity increase after the construction of the world's tallest building: An active blind fault beneath the Taipei 101. Geophys. Res. Lett., 32, L22313, doi: 10.1029/2005GL024223. [Link]

Lin, C. H., K. I. Konstantinou, W. T. Liang, H. C. Pu, Y. M. Lin, S. H. You, and Y. P. Huang, 2005: Preliminary analysis of volcanoseismic signals recorded at the Tatun Volcano Group, northern Taiwan. Geophys. Res. Lett., 32, L10313, doi: 10.1029/2005GL022861. [Link] 
Lin, C. S., 1957: Topography of Taiwan. Committee of Documentation, Taiwan Province, 303-314. (in Chinese)

Lin, C. W., H. C. Chang, S. T. Lu, T. S. Shih, and W. J. Huang, 2000: An Introduction to the Active Faults of Taiwan (Second Edition). Special Pub. 13, Central Geol. Surv., MOEA, Taipei, Taiwan, ROC, 122 pp.

Ma, K. F., C. H. Chan, and R. S. Stein, 2005: Response of seismicity to Coulomb stress triggers and shadows of the $1999 \mathrm{M}_{\mathrm{w}}=7.6$ Chi-Chi, Taiwan, earthquake. J. Geophys. Res., 110, B05S19, doi: 10.1029/2004JB003389. [Link]

Scholz, C. H., 1990: The Mechanics of Earthquakes and Faulting. Cambridge Univ. Press, New York, 439 pp.

Segall, P. and D. D. Pollard, 1980: Mechanics of discontinuous faults. J. Geophys. Res., 85, 4337-4350.

Shyu, J. B. H., K. Sieh, Y. G. Chen, and C. S. Liu, 2005: Neotectonic architecture of Taiwan and its implications for future large earthquakes. J. Geophys. Res., 110, B08402, doi: 10.1029/2004JB003251. [Link]

Teng, L. S., S. C. Wang, C. B. Chang, C. Hsu, P. B. Yuan, and P. Y. Chen, 1994: Quaternary strata frame of the Taipei basin. Proc. Joint Symposium on Taiwan Quaternary (5) and on Investigation of Subsurface Geology/ Engineering Environment of Taipei Basin, 129-135.

Toda, S., R. S. Stein, P. A. Reasenberg, J. H. Dieterich, and A. Yoshida, 1998: Stress transferred by the $\mathrm{M}_{\mathrm{w}}=6.9$ Kobe, Japan, shock: Effect on aftershocks and future earthquake probabilities. J. Geophys. Res., 103, 2454324565

Townend, J. and M. D. Zoback, 2000: How faulting keeps the crust strong. Geology, 28, 399-402, doi: 10.1130/0 091-7613(2000)28<399:HFKTCS>2.0.CO;2. [Link]

Tsai, Y. B., 1985: A study of disastrous earthquakes in Taiwan, 1683-1895. Bull. Inst. Earth Sci., Acad. Sin., 5, $1-44$.

Utkucu, M., S. S. Nalbant, J. McCloskey, S. Steacy, and Ö. Alptekin, 2003: Slip distribution and stress changes associated with 1999 November 12, Duzce (Turkey) earthquake $\left(\mathrm{M}_{\mathrm{w}}=7.1\right)$. Geophys. J. Int., 153, 229-241, doi: 10.1046/j.1365-246X.2003.01904.x. [Link]
Wang, C. Y., Y. H. Lee, M. L. Ger, and Y. L. Chen, 2004: Investigating subsurface structures and $\mathrm{P}$ - and $\mathrm{S}$-wave velocities in the Taipei Basin. Terr. Atmos. Ocean. Sci., 15, 609-628.

Wang, J. C., C. F. Shieh, and T. M. Chang, 2003: Static stress changes as a triggering mechanism of a shallow earthquake: Case study of the 1999 Chi-Chi (Taiwan) earthquake. Phys. Earth Planet. Inter., 135, 17-25, doi: 10.1016/S0031-9201(02)00175-9. [Link]

Wang, J. H., 1988: b values of shallow earthquakes in Taiwan. Bull. Seismol. Soc. Am., 78, 1243-1254.

Wang, J. H., 1998: Studies of earthquake seismology in Taiwan during the 1897-1996 period. J. Geol. Soc. China, 41, 291-336.

Wang, J. H., 2008: Potential earthquakes rupturing the Chinshan and Shangjiao faults in the Taipei Metropolitan Area. Terr. Atmos. Ocean. Sci. 19, 205-212, doi: 10.3319/TAO.2008.19.3.205(T). [Link]

Wang, J. H. and S. S. Ou, 1998: On scaling of earthquake faults. Bull. Seismol. Soc. Am., 88, 758-766.

Wang, J. H., K. C. Chen, and T. Q. Lee, 1994: Depth distribution of shallow earthquakes in Taiwan. J. Geol. Soc. China, 37, 125-142.

Wang, J. H., M. W. Huang, and W. G. Huang, 2006a: Aspects of $\mathrm{M} \geq 4$ earthquakes in the Taipei metropolitan area. West. Pac. Earth Sci., 6, 169-190.

Wang, R., F. Lorenzo-Martin, and F. Roth, 2006b: PSGRN/ PSCMP - A new code for calculating co- and post-seismic deformation, geoid and gravity changes based on the viscoelastic- gravitational dislocation theory. Comput. Geosci., 32, 527-541.

Wang-Lee, C. M. and T. P. Lin, 1987: The geology and land subsidence of the Taipei Basin. Mem. Geol. Soc. China, 9, 447-464.

Wells, D. L. and K. J. Coppersmith, 1994: New empirical relationships among magnitude, rupture length, rupture width, and surface displacement. Bull. Seismol. Soc. Am., 84, 974-1002.

Wu, F. T., 1978: Recent tectonics of Taiwan. J. Phys. Earth, 2 (Suppl.), S265-S299. 